E Q U I L I B R I U M

Volume 6 IsSue 4, 2011

IS S N $1689-765 \mathrm{X}$

Anna Adamik

Technical University of Lodz, Poland

\title{
Shaping Corporate Social Responsibility in the Conditions of Cultural Differences Between THE CoOpERATING Institutions
}

\section{JEL Classification Codes: $M 14$}

Keywords: corporate social responsibility (CSR), cultural differences in organizations, between-culture cooperation, national culture and organizational culture

\begin{abstract}
Corporate social responsibility (CSR) is not only a philosophy of acting for many companies, but a basic strategy for building a competitive advantage. Unfortunately, in the conditions when as a result of globalization the bonds of international cooperation are becoming stronger and stronger, it is increasingly difficult to shape. The factor of significant influence here is the partners' cultural diversity. Understanding the foundations of this diversity provides an opportunity to make more conscious decisions concerning the choice of partners and forms of cooperation. It also facilitates project-making and implementing CSR tools. The key issue here is the identification and evaluation of pro-social features of the partners' culture. Choosing the partners from the culture suitable for implementing CSR allows to maximize its benefits. The aim of this paper is to demonstrate the influence of national and organizational culture on the way of shaping CSR. In order to study the issue, the foundations of the topic, the nature of national and organizational culture, have been characterized. In addition, the underlying cultural differences and basic problems of shaping CSR have been signalled. The empirical demonstration of the issue are the results of CSR research in selected companies from different EU countries, but belonging to the same capital groups.
\end{abstract}

\section{Introduction}

Due to the ongoing globalization and the increasingly visible changes of companies' market behaviour, we can notice growing international bonds of cooperation between organizations. More and more companies, either operating on the local market, or expanding to Europe or worldwide market, engage in relations with foreign partners of various kind. Unfortunately, the connections are 
not as lasting and beneficial as both parties would wish. There is much evidence that an important reason for this type of problems is cultural mismatch or misunderstandings. Often originating from different cultures (both national and organizational), the partners perceive and evaluate the world differently, and not infrequently make contact with it and react to changes in a way which is incomprehensible for the other party. There is also a difference in a way they treat their social responsibility. It is the differing values and behavior types that actually form the character of an organization (its personality) distinct for each culture, as well as its potential, which together can significantly determine (strengthen or limit) the economic effectiveness of the parties which originate from it ${ }^{1}$.

It is worth analyzing the origins of such phenomena (the stronger influence of some cultures on higher efficiency and faster development of organizations originating from it) and how to use the knowledge to improve the efficiency of organizing international connections for cooperation between companies. It is also crucial to identify the influence of cultural differences on the perception, as well as extent and effectiveness of socially responsible actions (CSR) taken by the partners, as for many companies social responsibility is not only the accepted philosophy of conduct, but a strategy for building up competitive advantage based on ensuring lasting values not only to direct participants, but other stakeholders as well.

Thus, the aim of this paper will be demonstration of the role and influence of culture (national and organizational) on way of shaping social responsibility of companies involved in international connections. Theoretical analyses will be supported by the results of studies in several companies which are parts of two international capital groups: Recticel, with headquarters in Belgium, and Eurofoam, with headquarters in Austria.

\section{The nature of companies' culture and cultural differences}

Organizations differ not only with their size, structure or the type of operations, but also culture. There are three basic reasons for cultural differences among

${ }^{1}$ Such potential is built, for example, by Western-European culture. As it was already noticed in 1820, the West of Europe and its colonies and territories related to it (Australia, New Zealand, Canada and the USA) outdid other countries in terms of their income per capita. Over the years, the results have been confirmed by numerous studies, like the ones proving that in 1990 among the 30 richest countries in the world, as many as 21 were from Western Europe, or were related to it (the remaining ones were Japan, South Korea, Hong kong, Singapore, Taiwan and Kuwait, the United Arab Emirates, Chile and Israel). Although the population of the richest countries constitutes merely 16 per cent of the Earth population, it generates 87 per cent of scientific publications and 99 per cent of all European patents (Lewandowski 2008, p. 57). 
companies: 1) organizations are formed in a given cultural environment, which means a country of particular national culture and a region of distinctive regional culture, 2) each organization creates its own organizational culture, which is in some way a derivative of values followed by its management and employees (people coming from a given region, country, followers of a given religion, brought up in certain environments and according to certain family traditions), 3) culture is an entity composed of cognitive, emotional, intellectual and interpersonal elements of psychological and mental life; the whole of skills an individual acquires, uses and processes while taking part in relations and processes of social exchange (during learning, work and socializing) (Crozier, Friedberg 1982, p. 193), is thus time varying.

In order to understand the nature of situation described above, we should define what is culture as such, as well as national and organizational one. The next step should be determining the relations between them, how they affect each other and what impact it has on the studies by researchers of social phenomena, the theory of company management and the practice of social responsibility of contemporary business.

The issue of culture is widely described in literature, yet defined in many different ways. The most frequent, however, are several definitions formulated by classic authors. According to M. Mead, culture is shared behavior patterns (Mead 1973, p. 6). G. Hofstede, on the other hand, culture is collective mindprogramming, distinguishing members of one group from others (Hofstede 2000, p. 40). In the definition by Fukuyama we will find the conclusion that it is an ethical habit inherited by a given individual (Fukuyama 1997, p. 14). Bearing in mind the aims of this paper, it seems worthwhile to refer to the definition by P. R. Harris and R. T. Morgan, who see it as a way individuals react to "things" which is transmitted to next generations, or as a way of adapting to surrounding conditions and transmitting the skill and knowledge to next generations (so also the way of reacting to the needs and requirements of the paper's parties of interest) (Harris, Morgan 1987).

While analyzing the ways of perceiving national culture we can quote A. L. Kreober and C. K. M. Kluckhohn, according to whom national culture is the model of values, ideas and other symbolic, behavior-shaping systems which are transmitted in a given society (Kreober, Kluckhohn 1952, p. 19). At the same time it is worth noting here that this is not a common view, as there is an observable disagreement on the matter among the scholars. Some say that the national character of culture, a common definition of characteristics for the dwellers of the same territory, which make them distinguishable from the people living elsewhere is too artificial (non-existent). They claim that a society is usually a sum of numerous subcultures, which are not only difficult to define, and sometimes it is even impossible to find common elements they share (Kłosowska 1957, p. 109). 
Despite the abovementioned reservations, the supporters of former approach manage to identify distinctive features of various national cultures, which also result in specific skills and methods of work, specialization and advantage of certain countries in some aspects of business activity.

The third element of the cultural puzzle is organizational culture. Its definition is the most specific and narrow. The term usually denotes cultural system which distinguishes one organization from another, even among the ones functioning within the same society. Since each organization is a subjective creation formed by people in it, it is also a separate system of assumptions, values and models of conduct.

This way, according to some interpretations, organizational culture becomes equal to an organization's personality or identity, and according to other ones it is an organizational resource, composed of the elements which determine the behaviors of their members (Glińska-Neweś 2007, p. 140). It is developed along with the shaping of a specific: sense of identity (separateness, subjectivity, continuity), sense of control (ability to control oneself and the surrounding environment), self-esteem (awareness of one's value, confirmed by others) and adequate self-assessment (objective prediction of one's own ability) within an organization (Barabasz 2002, pp. 31-32).

Thanks to it companies create an organized and homogenous picture of a situation they operate in, concentrate on particular goals and aspirations, respond to things, people and situations, thanks to which their behavior becomes stable and repetitive. They thus create cultures characterized by particular features and strengths of positive or negative influence on the possibility of creating and developing, for instance, market competitiveness, economic effectiveness (Adamik 2010, pp. 153-170), bonds of cooperation between companies, innovative actions (Adamik 2011) or social responsibility. Positively evaluated cultures are characterized, among other features, by: pursuit of reducing complexities (for example, by means of cooperation), efficient communication network, quick decision-making, quick implementation of plans and projects, limited resources spent on supervision, strong motivation and loyalty, stability and reliability. The ones assessed negatively, on the other hand, tend to lock themselves in their shelves, block new ideas, have numerous implementation barriers, fixed patterns for success, collective attitude of evasion and lack of flexibility (Steinemann, Schreyogg 1992).

Such perception of organizational culture to a large extent determines the type of behavior and functioning of particular organizations in different market situations, as well as their effectiveness or simply the possibility of making use of given concepts of management. It also concerns the effectiveness of implementing the concept of social responsibility in business (CSR). It is the cultural assumptions of a particular company (the most deeply hidden in social awareness) and, perhaps even frequently, values, codes and attitudes, which are 
conscious ethical codes which tell organization members what should be done and how (which are two primary factors of organizational culture according to E Schein) (Schein, 1992, pp. 94-143) that mostly determine the levels on which it is developed, the tools used and the intensity of those actions.

All in all, in any case organizational culture originates from interactions between macro values (which derive from the national/state culture of the company's country of origin/operation), meso (which are the result of the generation, class, regional, branch or sector culture of the company's environment of operation) and micro (which are the values created during development and socialization of organization members). Thus in a given place and time it becomes possible to identify the features of organizational culture characteristic of, for example, the companies of a given country, region, market branch or sector. The similarities upon which the characteristics of particular cultures are founded usually concern the accepted organizational assumptions, like: attitude of the companies towards their environment, the attitude towards authority and power, relations between an individual and a group etc. which is then manifested in such types of organizational behavior as communication, teamwork or attitude towards changes (Glińska-Neweś 2007).

Identifying the studied cultures' accepted assumptions, values and approaches to certain issues allows for defining and classifying them. Such a conscious, analytical approach gives hints and clues concerning further actions not only to theoretical researchers, but practitioners as well. They are of special significance for those who have to be able to function (conduct analyses, manage, make decisions, negotiate, cooperate etc.) in the conditions of cultural diversity or cultural differences. The knowledge of which culture we represent, who we are dealing with or with which culture we are going to cooperate in the near future offers a chance of not only better understanding of the terms of cooperation or the specifications of partners' behavior, but most importantly of proper management of relations between particular stakeholders (including the socially responsible ones).

\section{Cooperation in the conditions of cultural differences}

Due to the nature of the ongoing economic changes, which lead to the transformation of traditional companies into networks of dispersed teams acting as recipients or servers on the basis of lasting interpersonal relations based on trust (Tapscott 1998), which are called relation organizations, (Keen 1991) relationship organizations (Mills 1991) or democratic companies (Ackoff 1994), it is increasingly frequent to talk about the functioning in the conditions of cultural differences. The fact that contemporary organizations base their functioning of 
a powerful network of mutual connections and relations with unlimited number of suppliers, partners, competitors, recipients and other parties of interest, often originating from different cultures, often poses significant organizational, decision-making and management difficulties, as it is impossible to be omniscient and able to cater for the needs of most of them and, what's equally important, be positively evaluated by them.

However, it seems that economic reality gives us some important hint on how to cope with this problem. Research shows that achieving convergence between cooperating organizational cultures, which means 'an organization's genetic code' forming repetitiveness of individual and collective behaviors within it, as well as reflections, emotions and attitudes (Aniszewska 2003, pp. 17-20), increases the degree of their cohesion and at the same time minimizes their willingness to change (break the relationships of cooperation) and creates long-term commitment and creativity of partners. The convergence can be worked out by systematically creating connections of cooperation and trust culture between partners.

Cooperation culture (Sikorski 2002, pp. 51-150) is based on creating the conditions for cooperation in a company by means of: promoting and connecting non-antagonistic cultures, selection of non-antagonistic co-workers, common belief in the benefits of cooperation, generating few conflicts, lack of prejudice, and developed network of informal connections. In such organizations cultural differences are respected and used in order to increase to company's human resources and competitiveness, communication processes are constantly improved to minimize the probability of conflicts and misunderstandings. In such conditions, the managers tries to effectively inspire, moderate and coordinate both existing and planned bonds of cooperation, inside and outside the organization, at the same time promoting ethical actions. Thus, one can often observe partnership in employee-employer or company-partner relations, the feeling of mutual dependence and collective problem-solving. Such attitude facilitates not only collective learning, but also creating something (Adamik 2011) in agreement with numerous stakeholders.

Culture of trust, on the other hand, refers to open, long-term ethical actions and relations based on trust resulting from the specific cultures observed by partners, methods of communication during daily actions and in relations with others, worked out by an organization.

They allow for making an assumption that a given individual, group or organization is competent, honest, reliable, interested and identifies with all parties' common goals, norms and values (Shockley-Zalabak, Ellis and Cesaria 2003). Such extraordinary relations, based on confirmed high trust and carried out with numerous partners create a specific atmosphere around a company, so called climate of trust. It creates the company's positive image not only in business environment, but outside it as well. The skills, resources, knowledge, close part- 
nership based on loyalty, clear business connections and other, often informal connections gained as a result of cooperation contribute to the unique 'culture of trust' among the cooperating parties as well as extraordinarily valuable, unique social capital (see: Adamik 2010, pp. 153-170).

Many sources also suggests that the factor which may turn out to be of great support in terms of coping with cultural differences is also appropriate selection of partners in terms of culture (which involves their proper identification and evaluation), as well as working to change or develop the partners' culture towards the desired one. In order to make the managers' job easier in this respect literature proposes a number of models, typologies and cultural characteristics. Taking into account the criteria of classifying organizational cultures which are described there, we can notice, for example, what type of culture we and our partner represent, which development-facilitating cultural features we (or our partners) possess, and which we still lack, in order to gain full benefits specific for our desired organizational culture. Possession of this knowledge allows us to take proper action, for example, to make investments.

One of the scholars who did research on this matter were L.E. Harrison and S. P. Huntington, who distinguished 10 values which constituted the difference between progressive (developmental) national cultures from conservative (antidevelopmental $)^{2}$. According to them, the abovementioned groups differ in terms of (Harrison, Huntington 2003):

- time orientation- progressive culture are characteristic of their focus on the future, whereas in conservative ones past and present are more important;

- attitude to work- in progressive cultures work is perceived as a source of satisfaction and self-respect, as well as the foundation of fulfilled life, whereas in conservative cultures work is considered a burden;

- attitude towards saving- in progressive cultures it guarantees financial stability, in conservative cultures it is perceived as a threat, compulsion;

- attitude towards education - in progressive cultures education is of primary importance, in conservative culture its significance is marginalized;

- attitude towards competence - in progressive cultures it is a resource which is essential for progress, whereas in conservative cultures it has been substituted by connections and support of the family;

- attitude towards community - in progressive cultures close relations reach far beyond one's family, in conservative cultures close bonds are limited to the inner circle of a community (family, friends);

- attitude towards ethical codes - in progressive cultures they are strictly followed (advanced democracies), unlike conservative cultures, where they are not executed (the level of corruption is high);

${ }^{2}$ The ten values described above is in accordance with the typology of pro- and anti-development cultures formulated by Mariano Grondona, which consists of 20 categories. 
- attitude towards justice and availability of professional career- justice and professional career are common in progressive cultures, in conservative ones they depend upon connections and health;

- attitude towards centralizing of power and the shape of hierarchiesin progressive cultures the authority aims at de-centralizing power and horizontal hierarchies, in conservative ones the model involves centralization and vertical structures;

- attitude towards secularism: in progressive cultures there is little influence of religious institutions on secular life, in progressive cultures the influence is significant.

Managers are also given some suggestions by M. E. Porter, who notices pro competition features (the ones which allow their representatives to compete more effectively on international markets) in some national cultures. The features are (Porter 2003, pp. 59-80):

- attitude towards sources of wealth, manifested by valuing productivity more than controlling assets and privileges;

- attitude towards the possibility of gaining wealth, according to which it is predominantly the result of creative potential and intuition, and is thus potentially unlimited;

- attitude towards perceiving external relations in terms of cooperation and competition, not monopoly, hierarchy and self-dependence.

Greatly contributing to the issue are the findings and conclusions by D. McClelland, who noticed that the level of a country's (or an organization's) economic development is related to the extent of spreading and social acceptance of certain psychological features, achievement motivation in particular. Individuals (organizations) which are achievement-oriented, are characteristic for their strong activity in all areas of life, pursuit of success and belief that it is within reach. They are more willing to make efforts, more persistent and able to work longer without rest. They also share a peculiar attitude towards time, which for them is more like a flying bird, which will disappear behind the horizon in a second, not like a calm ocean, which is motionless, - it passes quickly. They also constantly feel they do not have enough of it and are losing it forever. The past, present and future seem to be in close relation. In subjective terms, the latter comes faster and is imagined more easily and precisely. Probably that is why achievement-oriented individuals and companies tend to save up and insure themselves more often. An important issue here is their will to resign from immediate bonuses, in favour of the ones adjourned, but higher. It facilitates not only effort, but saving as well. Unfortunately, especially for CSR, individuals (organizations) geared for material success are often not socially active, are not members of any societies and do not usually contribute as citizens (studies by W. Rahn and J. Transue from 1998). It is a relatively big problem since, as D. McClelland and D. Winter have concluded, the biggest economic success is 
achieved by those groups which not only show strong motivation for achievements, but also pursue common good which reaches beyond personal issues and have a strong sense of social responsibility (McClelland, Winter 1969).

\section{Cultural differences and the responsibility of business}

When relating cultural differences to companies' social responsibility, it should be first reminded which actions are considered socially responsible. According to the European Commission, which organized the foundations of social responsibility on the European level in their Green Paper on CSR, it is a concept according to which companies willingly employ strategies involving social issues and environmental care, as well as partner relations with their stakeholders. It is founded upon actual social dialogue, creating transparent business relations and trying to find, in the process of the company's development and daily functioning, the solutions which take into account the interest of all parties involved in the company's activities, like employees, clients, suppliers, shareholders, competition and local communities. It also means running a business in a way which respects ethics, law, respect for the employees, local community and environment, in order to contribute to balanced development by cooperating with them, and to systematically raise the standard of life of all citizens. It also means such a strategy o running a company which due to conducting a social dialogue on a local level, contributes to the increase in a given company's competitiveness, developing its reputation and shaping positive conditions for social and economic growth (Rok 2004, p. 19). It is a strategic approach which leads to long-term profits by providing products and services with respect to ethics, law, honest fulfilment of obligations, without degrading natural environment.

However should we define CSR (having plenty of possibilities to choose from), it always concerns particular abilities of a company in terms of shaping relations with their social environment. The resources and culture of a given organization usually determine its activity in this field. Thus, we can encounter companies which in various ways incorporate social goals into their management process. According to one of the more popular approaches it can be done in several ways, like passive ${ }^{3}$,

${ }^{3}$ The passive strategy of company's social responsibility is carried out by lack of reaction to social problems. The company focuses solely on neutralizing conflicts which may negatively influence their functioning. The organization resists, avoids social responsibility, treating it as enforced by law, which is interpreted to the company's favor. The company's main goals are purely economical and it is responsible only for maximizing profits. 
reactive $^{4}$, pro-active ${ }^{5}$ or interactive ${ }^{6}$ (Adamczyk 2009, p.114). However, according to a more sophisticated approach by C.C. Walton, we can distinguish between CSR models which are (Rojek-Nowosielska 2008, pp. 72-74): 1) strict (aiming only at maximizing profits according to owners'/shareholders' expectations and creating responsibility with respect to them. There is no room there for implementing CSR concept); 2) family (according to which employees are the company's major concern and thus all social responsibility is built up in relation to them), sellers (focusing primarily on the customers- their rights, preferences and interests); 4) investors (assuming that a company's primary goal is its survival on a competitive market, with social actions being a potentially important tool, or even an investment essential for achieving this goal); civic (according to which a company realizes that by functioning inside a community it generates profits, but can also cause environmental damage or negative social consequences. As a conscious citizen and participant of social life it willingly engages in actions which are to minimize the negative consequences of its actions); 6) artistic (assuming that a company is aware of its power and range of influence, and thus feels responsible for creating better conditions of social life and actively participates in culture and civilization).

The abovementioned various socially responsible behaviours, according to the findings of long-term inter-cultural studies, for example G. Hofstede, F. Trompenaars, S.H, Schwartz, T. Parsons, E.T. Hall, R.D Lewis, R.R. Gesteland and many others, are usually the result of particular aspects and features of the companies' organizational cultures. The literature analyses conducted for the purpose of this paper allowed to distinguish the aspects most crucial for key areas of CSR. They are presented in the table 1 .

${ }^{4}$ Reactive strategy of company's social responsibility involves reacting to changes taking place in law and the surrounding environment. The company accepts and follows the regulations and secures the interests of stakeholders, which are legally guaranteed (like employees, suppliers, creditors, recipients). The company introduces changes under social pressure.

${ }^{5}$ Pro-active strategy of company's social responsibility involves initiating changes and influencing transformations in the environment. Such companies react to stakeholders' expectations before social problems appear. In order to do this, it studies their expectations and power, trying to strike a balance between the interests of various groups. Organizations aim at maintaining positive relations with the community by obeying the law and ethical code of conduct. They introduce innovative solutions, forcing the competitors to take similar actions.

${ }^{6}$ Interactive strategy of company's social responsibility involves reaching a harmony between the goals of the company and the ones of stakeholders. A company and its social partners look for ways and forms of creating worth. A company fulfills its social responsibility in economic, legal, ethical and philanthropic area. 
Table 1. Collection of cultural aspects determining (inhibiting or facilitating) socially responsible actions of companies

\begin{tabular}{|c|c|c|}
\hline $\begin{array}{c}\text { Aspects } \\
\text { of a com- } \\
\text { pany's social } \\
\text { respon- } \\
\text { sibility }\end{array}$ & Aspects inhibiting CSR & Aspects facilitating CSR \\
\hline $\begin{array}{l}\text { Relations with } \\
\text { employees }\end{array}$ & $\begin{array}{c}\text { Individualism } \\
\text { Universalism } \\
\text { Individualistic growth } \\
\text { Masculinity } \\
\text { Pro-transaction attitude } \\
\text { Moderation } \\
\text { Monochronism } \\
\text { Self-development } \\
\text { Non-conformism } \\
\text { Limited contacts } \\
\text { Reactivity } \\
\text { Being inner-directed } \\
\text { Selective approach }\end{array}$ & $\begin{array}{c}\text { Collectivism } \\
\text { Particularism } \\
\text { Transcendentism (care) } \\
\text { Femininity } \\
\text { Pro-partnership attitude } \\
\text { Emotionality } \\
\text { Polychronism (multi-activity) } \\
\text { Investments in development } \\
\text { Conformism } \\
\text { Openness to contacts } \\
\text { Pro-activity } \\
\text { Being outer-directed } \\
\text { Holistic approach }\end{array}$ \\
\hline $\begin{array}{l}\text { Relations } \\
\text { with business } \\
\text { partners } \\
\text { (clients, } \\
\text { suppliers, } \\
\text { competition } \\
\text { etc.) }\end{array}$ & $\begin{array}{c}\text { Non-conformism } \\
\text { Masculinity } \\
\text { Limited contacts } \\
\text { Risk-taking } \\
\text { Being inner-directed } \\
\text { Individualism } \\
\text { Pro-transaction attitude } \\
\text { Moderation } \\
\text { Monochronism } \\
\text { Individualistic growth }\end{array}$ & $\begin{array}{c}\text { Conformism } \\
\text { Femininity } \\
\text { Openness to contacts } \\
\text { Avoiding uncertainties } \\
\text { Being outer-directed } \\
\text { Collectivism } \\
\text { Pro-partnership attitude } \\
\text { Emotionality } \\
\text { Polychronizm (multi-activity) } \\
\text { Transcendentism (care) }\end{array}$ \\
\hline $\begin{array}{c}\text { Attitude } \\
\text { towards } \\
\text { natural } \\
\text { environment }\end{array}$ & $\begin{array}{c}\text { Interference into natural environment } \\
\text { Selective approach } \\
\text { Non-conformism } \\
\text { Being inner-directed } \\
\text { Universalism } \\
\text { Reactivity } \\
\text { Monochronism }\end{array}$ & $\begin{array}{c}\text { Free development of natural } \\
\text { environment } \\
\text { Holistic approach } \\
\text { Conformism } \\
\text { Being outer-directed } \\
\text { Particularism } \\
\text { Pro-activity } \\
\text { Polychronism (multi-activity) }\end{array}$ \\
\hline $\begin{array}{c}\text { Attitude } \\
\text { towards } \\
\text { philantropy }\end{array}$ & $\begin{array}{l}\text { Reactivity } \\
\text { Individualistic growth } \\
\text { Non-conformism } \\
\text { Masculinity } \\
\text { Monochronism } \\
\text { Moderation } \\
\text { Being inner-directed }\end{array}$ & $\begin{array}{c}\text { Pro-activity } \\
\text { Transcendentism (care) } \\
\text { Conformism } \\
\text { Femininity } \\
\text { Polychronism (multi-activity) } \\
\text { Emotionality } \\
\text { Being outer-directed }\end{array}$ \\
\hline
\end{tabular}




\section{continued table 1}

\begin{tabular}{|c|c|c|}
\hline $\begin{array}{c}\text { Attitude } \\
\text { towards } \\
\text { ethics }\end{array}$ & $\begin{array}{l}\text { Selective approach } \\
\text { Reactivity } \\
\text { Openness to changes } \\
\text { Short-term orientation } \\
\text { Individualistic growth }\end{array}$ & $\begin{array}{c}\text { Holistic approach } \\
\text { Pro-activity } \\
\text { Conservatism } \\
\text { Long-term orientation } \\
\text { Transcendentism (care) }\end{array}$ \\
\hline $\begin{array}{c}\text { Attitude } \\
\text { towards } \\
\text { law }\end{array}$ & $\begin{array}{l}\text { Openness to changes } \\
\text { Risk-taking } \\
\text { Reactivity } \\
\text { Short-term orientation } \\
\text { Monochronism } \\
\text { Pro-transaction attitude } \\
\text { Universalism }\end{array}$ & $\begin{array}{c}\text { Conservatism } \\
\text { Avoiding uncertainties } \\
\text { Pro-activity } \\
\text { Long-term orientation, } \\
\text { Polychronism (multi-activity) } \\
\text { Pro-partnership attitude } \\
\text { Particularism }\end{array}$ \\
\hline $\begin{array}{l}\text { Attitude } \\
\text { towards } \\
\text { company } \\
\text { develop- } \\
\text { ment }\end{array}$ & $\begin{array}{c}\text { Short-term orientation } \\
\text { Analysis } \\
\text { Limited outside contacts } \\
\text { Reactivity } \\
\text { Universalism } \\
\text { Individualism } \\
\text { Masculinity } \\
\text { Risk-taking } \\
\text { Self-development }\end{array}$ & $\begin{array}{c}\text { Long-term orientation } \\
\text { Synthesis } \\
\text { Openness to outsider contacts } \\
\text { Pro-activity } \\
\text { Particularism } \\
\text { Collectivism } \\
\text { Femininity } \\
\text { Avoiding uncertainties } \\
\text { Investing in development }\end{array}$ \\
\hline
\end{tabular}

Source: collected on the basis of: G. Hofstede (2000), Kultury i organizacje, PWE, Warszawa; F. Trompeneaars, Ch. Hampden-Turner (2002), Siedem wymiarów kultury. Znaczenie różnic kulturowych w działalności gospodarczej, Oficyna Ekonomiczna, Kraków; T. Parsons (1951), The Social System, Free Press, New York; E. Shein (1992), Organizational Culture and Leadership, Jossey-Bass Publishers, San Francisco; S. H. Schwartz (1994), Beyond the Individualism/Collectivism: New Cultural Dimensions of Values, [in:] U. Kim, H.S. Hakhoe (ed.) Individualism and Collectivism: Theory, Method, and Applications,Sage Publications, Thousand Oaks; E. T. Hall, M. R. Hall (1990), Understanding Cultural Differences, German, French and Americans Intercultural Press, Inc.; R. R. Gesteland (1999), Różnice kulturowe a zachowania $w$ biznesie, PWN, Warszawa; R. D. Lewis (2006), When Cultures Collide. Leading Across Cultures, Nicolas Breadley Publishing; A. Glińska-Neweś (2007), Kulturowe uwarunkowania zarzqdzania wiedza w przedsiębiorstwie, Dom Organizatora, Toruń.

It seems that identifying (as existent or non-existent) the behaviors and characteristics from the last column in Table 1 within a company can tell a lot about the organization's cultural pre-dispositions to successfully implement CSR. When treating this column as a company's CSR checklist, the ones which possess most of the features included there can be considered as ones with pro-social culture, whereas those who lack the features listed (mostly characterized by the second column) are organizations of traditional culture. We can thus expects more altruism, openness to cooperation, partnership, ethical code of conduct, transparency, care for employees, natural environment and the stakeholders' 
needs from the companies from the first group. The second group of companies, on the other hand, are mostly self-oriented partners, independent, managed with an iron fist in order to make short-term profits for the owners. Obviously, even this simple tool can be of assistance for managers in order to properly diagnose many business situations when cultural differences occur. It allows for making a decision who should or should not be chosen as a partner. It also helps to understand from whom we can or cannot count on partnership, ethical conduct or support. Thus, cultural diversity does not necessarily cause problems. Sometimes, it can just as well pose a chance for development, as well as solid foundation for loyal and long-term cooperation. Thanks to the expanding knowledge about specifications of different organizational cultures and such, and similar, analyses it is increasingly easier to make decisions concerning cooperative relations of various kind.

\section{Practical aspects of corporate social responsibility in multi-national groups of partners}

Cultural differences in terms of approach to corporate social responsibility are most clearly visible among the EU countries. Different countries (with different national cultures) promote to a varying extent and with varying dedication the creation of conditions favorable for social responsibility on their territory. It can be directly reflected in the CRS-related activity of companies coming from them. The countries which actively promote corporate social responsibility are: Great Britain, Holland, Belgium and Denmark. On the other hand, Germany, Austria and France are skeptical about it, justifying themselves with a well-established internal regulations which obliges companies to act responsibly. The countries of Southern Europe engage in CRS actions to a smaller extent, which can be explained with their traditional and paternalistic nature of business. It does not, of course, mean that no such actions are taken, but merely that the concept of CSR is not viewed upon as an important element of business. Minimal CSR actions are also taken in Luxembourg, Greece and Portugal (Nakonieczna 2008, pp. 131-138). "A Guide to CSR in Europe" (see: A Guide to CSR in Europe, 2009) also concludes that the EU countries tend to give priority to actions related to environmental care, stopping climate changes and ecological effectiveness. In Belgium, Poland and Hungary there is a special focus on making corporate activities transparent. Actions encouraging social reporting are also undertaken. In Austria, Poland and Italy, much attention is given to safety at work. In single cases, actions against social exclusion are taken (for example, in Portugal).

What can be seen as an interesting reflection of the abovementioned generalizations is a short analysis of CSR actions taken by companies from two international corporations with joint capital: Recticel, with its headquarters in Belgium, 
and Eurofoam, with headquarters in Austria ${ }^{7}$. The Recticel group operates in b2b (business to business) and b2c (business to consumer) market, whereas the Eurofoam group operates mainly on $b 2 \mathrm{~b}$ market. The following companies have been chosen for study: 1) Recticel N.V., with headquarters in Wetteren (Belgium); 2) Recticel Komfort Snu limted, with headquarters in Łódź (Poland); 3) Eurofoam Polska limited, with headquarters in Zgierz (Poland); 4) Eurofoam GmbH, with headquarters in Kremsmünster (Austria). The analysis of their CSR-related activity is presented in Table 2.

As seen above, empirical evidence confirms the theory. If we assume that companies 1) and 3) (Recticel) and 2) and 4) (Eurofoam) not only have similar size and resources, but also belong to the same capital groups, thus representing similar organizational culture, then they should carry out their basic tasks, in this case: socially responsible ones, in a similar manner. However, it seems that the companies studied have different achievements in this field, arguably due to coming from different countries and thus enjoying different operating conditions. In the companies when CSR is systematically and more actively implemented (which means the ones where pro-social aspects of national culture are reinforced with particular tools of gaining social influence), the achievements in the field are more significant (more efficient pro-social organizational culture of companies in a given country). A model example here seems to be Belgium and the Recticel branch which operates there. It got the highest marks in all CSRrelated areas studied. Eurofoam from Austria, known for its skepticism towards CSR came second, with companies from Poland, still learning CSR, receiving the lowest marks. Naturally, the selected examples do not form a basis for generalizations, but they show a particular tendency of cultural characteristics (in this case national culture) influencing the differences in attitudes and codes of conduct (in this case organizational social culture). Thus, by observing the partners' origins the processes of shaping various types of relations can be more efficiently handled.

${ }^{7}$ The study was carried out on the basis of documents presented by the companies, the information available on their websites, as well as a standard interview based on standard questionnaire. The range of study based on the interview can be defined as general, concerning the perception and implementation of CSR concept in a company. In the cases of companies located abroad, the study was carried out via e-mail. The original study material was collected for the purpose of the thesis by M. Salska, who was writing a BA thesis under tutorship of the author. 


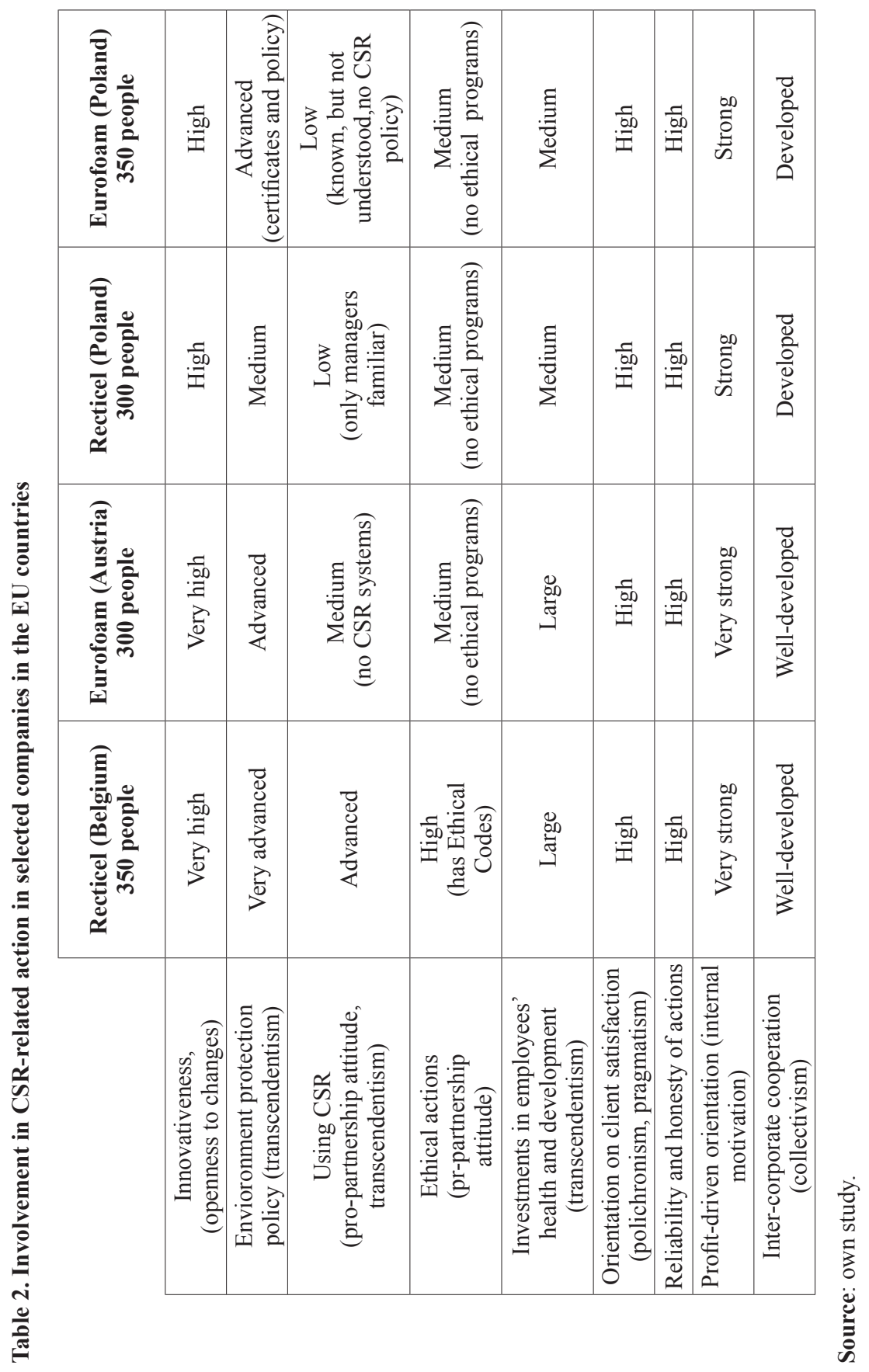




\section{Conclusions}

It is definitely not an easy task for a company to function in the conditions of cultural differences, but appropriate knowledge and tools of supporting decisionmaking in relation to cooperation in such conditions increase the chances of success. It also concerns efficiency in carrying out socially responsible actions. Since, as shown above, broadly defined culture determines inclination, activity, dedication and effectiveness of companies in CSR-related action, it seems essential for the managers, as well as local and state authorities to consciously influence and stimulate pro-social changes in national, as well as organizational, cultures of countries and organizations governed in a modern manner. Institutional support from the authorities which shape national cultural attitudes in the field of social responsibility should thus be monitored, made use of and demanded to the largest extent possible, in order to effectively influence the development of organizational practice of CSR.

\section{Literature}

A Guide to CSR in Europe. Country Insights by CSR Europea's National Partner Organisations (2009), October.

Ackoff R.L. (1994), The Democratic Corporation, Oxford University Press, New York.

Adamczyk J. (2009), Społeczna odpowiedzialność przedsiębiorstw. Teoria i praktyka, Polskie Wydawnictwo Ekonomiczne, Warszawa.

Adamik A. (2010), Kultura zaufania jako determinanta efektywności procesów wspótpracy międzyorganizacyjnej, [in:]Adamik A. (ed.), Zarządzanie relacjami międzyorganizacyjnymi. Doświadczenia $i$ wyzwania, „Monografia Politechniki Łódzkiej” nr 1928, Wydawnictwo Politechniki Łódzkiej, Łódź.

Adamik A. (2011), Kulturowe uwarunkowania skuteczności działań innowacyjnych przedsiębiorstw, „Współczesne Zarządzanie” (w druku).

Aniszewska G. (2003), Geneza pojęcia „,kultura organizacyjna”, „Przegląd Organizacji, nr. 10,

Barabasz A. (2002), Osobowość organizacji, [in:] H. Jagoda, J. Lichtarski (ed.) Nowe kierunki $w$ zarzqdzaniu przedsiębiorstwem. Integracja $i$ dezorganizacja, Prace Naukowe AE im. Oskara Langego we Wrocławiu, Wyd. AE im. O. Langego We Wrocławiu, Wrocław.

Crozier M, Friedberg E. (1982), Człowiek i system, ograniczenia działania zespołowego, PWE, Warszawa.

Fukuyama F. (1997), Zaufanie. Kapitat społeczny a droga do dobrobytu, Wydawnictwo Naukowe PWN, Warszawa-Wrocław.

Glińska-Neweś A. (2007), Kulturowe uwarunkowania zarzq̨dzania wiedzq w przedsiębiorstwie, Dom Organizatora, Torun,

Harris P. R., Morgan R. T. (1987), Managing Cultural Differences, Gulf Publishing Co, Houston

Harrison L. E., Huntington S. P. (red.) (2003), Kultura ma znaczenie, Wydawnictwo Zysk i S-ka, Poznań.

Hofstede G. (2000), Kultury i organizacje, PWE, Warszawa. 
Keen P. (1991), Shaping the Future: Business Design Through Information Technology, Harvard Business School Press, Boston, MA.

Kłoskowska A. (1957), Charakter narodowy a osobowość we wspótczesnej problematyce badań społecznych, „Kultura i Społeczeństwo”, t. I.

Kroeber A. L., Kluckhohn C. K. M. (1952), Culture, Meridian Books, New York.

Lewandowski A. (2008), Kultura a dobrobyt, Personel Plus, 9.

McClelland D. C., Winter D.G. (red.) (1969), Motivating economic achievement, Free Press, New York, Collier-Macmillan, London, New York.

Mead M. (1973), Coming of Age in Samoa, Modern Library, New York.

Nakonieczna J. (2008), Społeczna odpowiedzialność przedsiębiorstw, Difin, Warszawa.

Porter M. E. (2003), Postawy, wartości i przekonania a makroekonomia dobrobytu, [in:] L. E. Harrison, S. P. Huntington (ed.), Kultura ma znaczenie, Wydawnictwo Zysk i S-ka, Poznań.

Rojek-Nowosielska M. (2008), System i modele społecznej odpowiedzialności przedsiębiorstw, [in:] Pisz Z. (ed.), Społeczna odpowiedzialność przedsiębiorstw, Prace Naukowe Uniwersytetu Ekonomicznego we Wrocławiu, 5 (1205), Wyd. Uniwersytetu Ekonomicznego we Wrocławiu, Wrocław.

Rok B. (2004), Odpowiedzialny biznes w nieodpowiedzialnym świecie, Akademia Rozwoju Filantropii w Polsce, Forum Odpowiedzialnego Biznesu, Warszawa.

Shein E.(1992), Organizational Culture and Leadership, Jossey-Bass Publishers, San Francisco.

Sikorski Cz. (2002), Kultura organizacyjna, C.H. Beck, Warszawa.

Steinmann H, Schreyogg G. (1992), Zarzadzanie. Podstawy kierowania przedsiębiorstwem, Wyd. Politechniki Wrocławskiej, Wrocław.

Tapscott D. (1998), Gospodarka cyfrowa, Businessman Book, Warszawa. 

E Q U I L I B R I U M

Volume 6 IsSue 4, 2011

IS S N $1689-765 \mathrm{X}$

\title{
Agnieszka Werenowska, Tomasz Stankiewicz Warsaw University of Life Sciences, Poland
}

\author{
Corporate Social Responsibility \\ in The Polish Companies
}

JEL Classification Codes: $M 14$

Keywords: social responsibility, company, levels of CSR

\begin{abstract}
The aim of this study was the attempt to investigate corporate social responsibility in the selected Polish companies. During the research procedure it was possible: to determine general awareness in the investigated companies in terms of their social responsibility activities; to determine the level of competence and the use of available tools as well as CRS standards. Due to the established aims of research, the following assumptions were formulated: Corporate social responsibility plays a significant role in the business activities that are undertaken by the researched companies. Selected Polish companies abide by international CRS quality standards.
\end{abstract}

\section{Introduction}

The concept of corporate social responsibility is still a new subject, which accompanies crucial decisions in many companies. On the other hand, this complex idea has a long history. It dates back to $18^{\text {th }}$ century, when it was connected with philanthropy and was not identified with the company itself. However, over the course of time its "disinterested simplicity" changed into a particular business tool, which determines strategies adopted, among others, by managers. CSR, which has still been developing, sets standards of interaction quality with stakeholders. Thus, it also gives an impulse for positive changes in business. Over the last ten years, broadly defined Polish society has changed the way CSR is perceived. A company, which undertakes CSR activities compares favourably with the one, which does not include stakeholders in its activities (Mazurkiewicz 2006, p. 22). 


\section{Social responsibility standards}

Corporate Social Responsibility is the idea that undoubtedly left a mark in the development of the global economy last year. It contributed to a more detailed examination of the companies which declare ethical and sustainable activities. Year by year, more and more organizations publish codes and social reports.

Over the course of time, the act of asking people from the circles of the company, thus the public as well, about the actually completed ethical principles, included in the companies' programs, becomes more and more popular. The question arose due to more and more frequent disparity between the code which officially determines the company's policy and the prosaic or natural decisions in the company.

It was not long before the business replied. As CSR was developing, clearer procedures and standards were being introduced. They enabled to "install" sustainable development more easily at the operational and strategic level of the company. Since the early 90 's of the last century, it was common among the companies to undergo ethical and social audits, which made their image more positive.

\section{Methods, internal systems and institutions measuring CSR}

The company's activities, which are well thought-out and socially responsible, usually have the quality aspect. However, despite this fact, only the quantitative aspect can be used to measure their effectiveness. That is why the world of business had to establish certain measurements, which would estimate the effectiveness and appropriateness of CSR implementation in the company (analyzing at the same time the assessment scheme incorporated by external benchmarking and rating companies) in an easy and effective way.

As Bolesław Rok emphasizes sample quantitative indicators, broadly used in CSR reports, can be distinguished. Due to these indicators, the assessment of the scale of efforts made by the organizations for socially responsible activities becomes possible (table 1). Another issue is using external tools, such as stock exchange indices. 